\title{
Cardiocladius oliffi (Diptera: Chironomidae) as a potential biological control agent against Simulium squamosum (Diptera: Simuliidae) Daniel A Boakye ${ }^{* \dagger 1}$, Eric Fokam ${ }^{\dagger 2}$, Anita Ghansah ${ }^{\dagger 1}$, Josef Amakye ${ }^{\dagger 3}$, Michael D Wilson ${ }^{\dagger 1}$ and Charles A Brown ${ }^{\dagger 1}$
}

\author{
Address: ${ }^{1}$ Noguchi Memorial Institute for Medical Research, Box LG581, Legon, Accra, Ghana, ${ }^{2}$ Department of Life Sciences, University of Buea, \\ Cameroon and ${ }^{3}$ Water Research Institute, CSIR, P.O. Box 38, Achimota, Ghana \\ Email: Daniel A Boakye* - dboakye@noguchi.mimcom.org; Eric Fokam - efokam@yahoo.com; \\ Anita Ghansah - aghansah@noguchi.mimcom.org; Josef Amakye - jsamakye@yahoo.com; Michael D Wilson - mwilson@noguchi.mimcom.org; \\ Charles A Brown - cbrown@noguchi.mimcom.org \\ * Corresponding author †Equal contributors
}

Published: 24 April 2009

Parasites \& Vectors 2009, 2:20 doi:10.1186/1756-3305-2-20

This article is available from: http://www.parasitesandvectors.com/content/2/l/20

(C) 2009 Boakye et al; licensee BioMed Central Ltd.

This is an Open Access article distributed under the terms of the Creative Commons Attribution License (http://creativecommons.org/licenses/by/2.0), which permits unrestricted use, distribution, and reproduction in any medium, provided the original work is properly cited.

\begin{abstract}
Background: The control of onchocerciasis in the African region is currently based mainly on the mass drug administration of ivermectin. Whilst this has been found to limit morbidity, it does not stop transmission. In the absence of a macrofilaricide, there is a need for an integrated approach for disease management, which includes vector control. Vector control using chemical insecticides is expensive to apply, and therefore the use of other measures such as biological control agents is needed. Immature stages of Simulium squamosum, reared in the laboratory from egg masses collected from the field at Boti Falls and Huhunya (River Pawnpawn) in Ghana, were observed to be attacked and fed upon by larvae of the chironomid Cardiocladius oliffi Freeman, 1956 (Diptera: Chironomidae).
\end{abstract}

Methods: Cardiocladius oliffi was successfully reared in the rearing system developed for $S$. damnosum s.l. and evaluated for its importance as a biological control agent in the laboratory.

Results: Even at a ratio of one $C$. oliffi to five $S$. squamosum, they caused a significant decrease in the number of adult $S$. squamosum emerging from the systems (treatments). Predation was confirmed by the amplification of Simulium DNA from C. oliffi observed to have fed on S. squamosum pupae. The study also established that the chironomid flies could successfully complete their development on a fish food diet only.

Conclusion: Cardiocladius oliffi has been demonstrated as potential biological control agent against S. squamosum.

\section{Background}

Human onchocerciasis has been controlled as a disease of public health and socio-economic importance in parts of West Africa covered by the Onchocerciasis Control Programme (OCP), primarily through vector control. How- ever, the blackfly vectors (various sibling species of Simulium damnosum Theobald complex) were not eliminated. Therefore, after cessation of vector control, re-colonization of the onchocerciasis-freed zones by the vectors has occurred, and this could lead to recrudescence of the 
disease if there are residual infections in the human population. These fears were allayed when mass treatment with ivermectin and the resultant massive reductions in microfilariae indicated that long-term treatments could lead to interruption of transmission. The return of the flies was therefore considered to pose only a biting nuisance and not a health risk, although anaphylactic shock, probably resulting in persons exposed to mass biting of two Simulium species in the English Midlands, has been reported [1].

There are no reports of the economic impact of the nuisance of $S$. damnosum s.l. in monetary terms [2]. However, Jamnback [3] reported that, in areas of major developmental projects, the incessant bites could be a serious threat to economic success. In Côte d'Ivoire, it was reported in the press (Jeune Afrique Economie, 1999, 106, 285) that farmers in the oncho-freed zones around the Leraba, Bou and Fombou rivers could only work between $1000 \mathrm{H}$ and $1530 \mathrm{H}$ due to $S$. damnosum s.l. biting nuisance. This translates into 2.5 hours of work lost, in addition to forcing the farmers to work during the hottest hours of the day. In Ghana, a possible negative impact of the biting nuisance on tourism was observed around the Kakum National Park during the rainy season in 1999 (Dr Kofi Ahmed et al, MOH unpublished report).

Recent information [4] indicates that elimination of transmission with ivermectin may not be feasible in all instances. There may be resistance to ivermectin in populations of Onchocerca volvulus [5]. Also, Boakye et al[6] showed that members of the $S$. damnosum s.l. can pick-up parasites at infection levels as low as $0.1-1.0 \mathrm{mf} / \mathrm{mg}$ skin and that these parasites could develop to the infective stage. Thus, apart from the biting nuisance, the presence of low levels of infection and the return of blackflies into the onchocerciasis freed zones could lead to a resurgence of onchocerciasis. There is therefore the necessity to continue to reduce blackfly density in areas of economic activity, as well as in the onchocerciasis-controlled areas of West Africa.

Large-scale vector control using chemicals is costly and, if not properly implemented, can result in serious environmental consequences. Hence, there is the need to find alternative methods that are cheap in the longer term, selfsustaining and relatively environmentally safe. The use of bio-control agents against pests of economic importance meets these criteria. Various organisms prey on, or infect, the different life stages of $S$. damnosum s.l., but few have been seriously evaluated for their usefulness as biological control agents. One group of organisms that need evaluating are larvae of the genus Cardiocladius (Family: Chironomidae), which are known predators of blackflies [7]. Unfortunately, none of the four species reported to breed in Africa has been recorded in West Africa [8], but recently C. oliffi was identified and described at an S. damnosum s.l. breeding site in Ghana and observed to feed on pupae of S. damnosum s.l. [9]. We report here the evaluation of this species in the laboratory as a potential biological control agent of $S$. squamosum.

\section{Methods}

Collection and identification of C. oliffi and S. squamosum Egg masses of C. oliffi and S. squamosum were collected from Boti Falls (R. Pawnpawn $\left(6^{\circ} 12^{\prime} \mathrm{N}\right.$ and $\left.0^{\circ} 13^{\prime} \mathrm{W}\right)$ in the rainy seasons (June - July) of 1999 and 2000. The samples were transported under moist conditions in wet plastic bags placed in an ice box to the laboratory for rearing to adults. Leaves with attached egg masses were cut into smaller pieces (approx. $2 \mathrm{~cm}^{2}$ ) and a thread passed through each piece and the thread attached to the tubing just above the air stone of the rearing system described in Boakye et al[10]. Rearing was done as described in Boakye et al[10]. Briefly, the tubing with the attached eggs was placed in a poly tube in a beaker filled with river water. The other end of the plastic tubing was fixed on to an Hyflo $^{\circledR}$ aeration pump. Air is pumped through the airstone and the air bubbles coming through the poly tube creates a current sufficient to support the development of the aquatic stages of both the S. squamosum and C. oliffi. The rearing temperature was $28^{\circ} \mathrm{C}$. The identification keys of Wiederholm [11,12] and Freeman [13] were used to identify C. oliffi. Simulium squamosum species were identified by cytotaxomy [14]. The chromosome slides for $S$. squamosum are deposited in the Parasitology Department of Noguchi Memorial Institute for Medical Research.

\section{Evaluation of C. oliffi as a biological control agent of S. squamosum}

Five ratios of $C$. oliffi larvae to $S$. squamosum larvae; 0:25 (control), 1:5, 1:2, 1:1 and 25:0 were placed in different rearing systems and monitored for S. squamosum larval and pupal mortality and adult emergence. Each experiment started with 25 S. squamosum larvae per rearing system and the chironomid larvae varied with the exception of the system that had no $S$. squamosum. Six replicates were undertaken for each experimental regime except the last, which had four replicates. Fish food (Tetrafin ${ }^{\circledR}$ Goldfish Flakes, Tetra, Blacksburg, VA) was provided daily in both the control and predation treatments. About $200 \mathrm{mg} /$ tray of the feed was used in feeding the larvae. The rearing systems were cleaned everyday and the number of larvae and pupae dead or alive and adult emerged was recorded. The temperature during the trials was $28^{\circ} \mathrm{C}$.

Significant differences between $S$. squamosum adults emerging from the separate treatment groups and the con- 
trol were tested with one-way ANOVA using Dunnett's Method in SigmaStat 3.1 (Systat Software, USA).

Demonstration of C. oliffi as a predator of S. squamosum A positive implication of C. oliffi as a predator on S. squamosum was demonstrated using PCR-RFLP of a segment of the 28S ribosomal RNA gene. Genomic DNA was extracted from 1) eight larvae of C. oliffi not observed to have fed on $S$. squamosum, 2) thirteen larvae of C. oliffi observed to have fed on S. squamosum and 3) ten larvae of S. squamosum using the method of Flook et al[15]. PCR amplification of the gene segment of interest was done using the primers P1 (5'-TAGTGACGCGCATGAATGGA3') and P2 (5'-GACGTCGCTATGAACGCTTGGC-3') [16] and following the above protocol [15]. The PCR products were visualised on $2 \%$ agarose gel stained in ethidium bromide.

Positive PCR products from the 3 experimental groups (unfed larvae of C. oliffi, fed larvae of C. oliffi and larvae of $S$. squamosum) were digested with the restriction enzyme AluI following the manufacturer's instructions. The restriction fragments were visualised on $2 \%$ agarose gels stained with ethidium bromide, and the size variation recorded.

\section{Results}

A total of 600 S. squamosum larvae and 358 C. oliffi larvae were used in the experiments. It was observed that larvae of C. oliffi attempted to grasp larvae of S. squamosum but were never successful as the $S$. squamosum larvae simply detached and moved away. However, these disturbances may have led to some larval mortality as indicated in the low numbers of pupae formed: 55 (36.6\%), 42 (28\%) and $28(18.6 \%)$ in the experimental groups compared to the control group 96 (64\%) (Table 1).

The C. oliffi larvae were successful in feeding on pupae of $S$. squamosum because these were not mobile. A greater proportion (81 specimen, 54\% of total) of adult S. squamosum flies emerged from the control compared with 22 (14.67\%), $15(10.0 \%)$ and $1(0.67 \%)$ from the treatment groups. The difference was significant (ANOVA, $F=620, p$ $<0.0001, d f=3)$. Of the 358 C. oliffi larvae used in the experiments, 315 (87.99\%) successfully completed their development to adults. There was no significant difference $\left(\chi^{2}=7.843, d f=6, p=0.250\right)$ between the proportion of adult $C$. oliffi that emerged from the control and the proportion of adult of the same species emerging from the various treatments.

The PCR generated fragments were approximately $800 \mathrm{bp}$ for all the specimens, hence it was not possible to distinguish S. squamosum from C. oliffi upon electrophoresis (Fig 1). However, the AluI restriction of the 800 bp PCR products showed variation in fragments sizes, indicating restriction site differences between the two species groups (Fig 1). It was therefore possible to show that C. oliffi had ingested $S$. squamosum by PCR amplification followed by AluI digest (Fig 1 lane 5).

\section{Discussion}

Benthic insects that prey on the $S$. damnosum complex have been identified in West Africa $[17,18]$, and the Trichoptera of the family Hydropsychidae were considered important predators in Côte d'Ivoire. Similar observations were also made in Ghana [19]. However, none of these studies identified chironomids as predators of the $S$. damnosum complex leading Service and Elouard [17] to conclude that one Orthocladiinae species, that showed a positive precipitin reaction to $S$. damnosum antiserum, was probably due to contamination. This is therefore the first report of a chironomid preying on S. damnosum s.l. in West Africa. Outside of Africa, species of chironomids [2023], particularly, larvae of Cladiocladius species [7], have been observed feeding on larvae and egg masses of black flies. The importance of predation of species of Cladiocla-

Table I: Numbers and proportions of pupae and adults obtained for the different experimental groups.

\begin{tabular}{|c|c|c|c|c|c|c|}
\hline \multirow[t]{2}{*}{$\begin{array}{l}\text { Experimental group } \\
\text { (C. oliff:S. squamosum) }\end{array}$} & \multicolumn{2}{|c|}{$\begin{array}{l}\text { Number of larvae introduced in the rearing } \\
\text { systems }\end{array}$} & \multirow{2}{*}{$\begin{array}{l}\text { Number of } S . \\
\text { squamosum pupae } \\
\text { (\% of larvae) }\end{array}$} & \multicolumn{3}{|c|}{ Adults S. squamosum emerged } \\
\hline & C. oliffi* & S. squamosum & & $\begin{array}{l}\text { Total number } \\
\text { (Mean + SD) }\end{array}$ & $\%$ of larvae & $\%$ of Pupae \\
\hline Control $(0: 25)$ & 0 & 150 & $96(64)$ & $81(14 \pm 3.94)^{a}$ & 54.00 & 84.38 \\
\hline Treatment ii (I: 5) & 30 & 150 & $55(36.6)$ & $22(4 \pm 2.94)^{b}$ & 14.67 & 40.00 \\
\hline Treatment iii (I: 2) & 78 & 150 & $42(28.0)$ & $15(3 \pm 2.16)^{b}$ & 10.00 & 35.71 \\
\hline Treatment iv (I: I) & 150 & 150 & $28(18.6)$ & $\mathrm{I}(0.20 \pm 0.48)^{\mathrm{b}}$ & 0.67 & 3.57 \\
\hline Treatment $\vee(25: 0)$ & 100 & 0 & - & - & & \\
\hline Total & 358 & 600 & & & & \\
\hline
\end{tabular}

Values followed by different letters are significantly different $(p<0.05)$.

$*$ There was no significant difference between the proportion of adult $C$. oliffi that emerged from the control and the proportion of adult of the same species emerging from the various treatments 


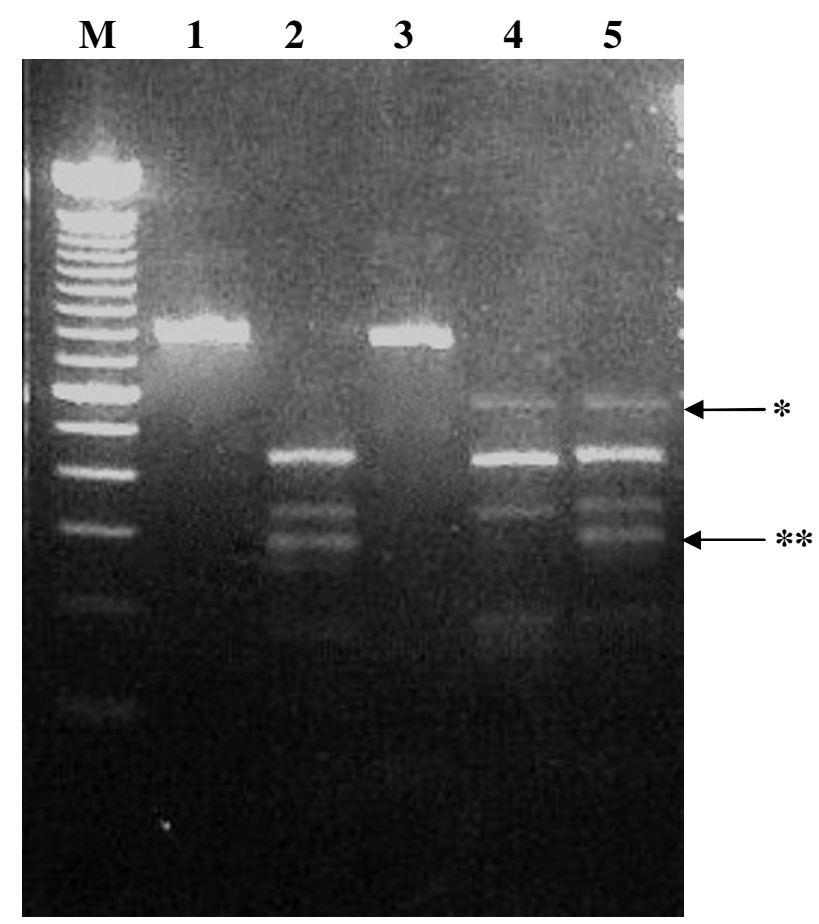

Figure I

P I/P2 PCR products and Alul restriction digests. Alu I restriction digest of PI/P2 PCR products of $S$. squamosum and $C$. oliffi showing differences between the two species. Lanes: $M=100$ bp ladder, I = Undigested PI/P2 S. squamosum PCR amplified product, 2 = Alu I digested PI/P2 S. squamosum PCR amplified product, $3=$ Undigested PI/P2 C. oliffi PCR amplified product, 4 = Alu I digested PI/P2 C. oliffi PCR amplified product, 5 = Alu I digested PI/P2 S. squamosum fed C. oliffi PCR amplified product. * Band specific for $C$. oliffi. ** Band specific for S. squamosum.

dius on blackflies led to an attempt to use C. australiensis to control blackfly populations in Australia [24].

The use of molecular biological methods to implicate $C$. oliffi as a predator shows the potential of this technique for future identification of predators. The laboratory evaluation of $C$. oliffi as a potential biological control agent indicated that, whilst the predation by this species clearly resulted in fewer adult $S$. squamosum emerging from the systems, it could also complete its life cycle in the absence of S. squamosum. This means that C. oliffi is not an obligate predator on $S$. squamosum. Nevertheless, all of the $S$. squamosum egg masses collected from the study site were infested with $C$. oliffi during the collecting period. Although, predators may not provide effective control, they may nevertheless be important in regulating population size [17]. The predation of C. oliffi should therefore be assessed in a natural setting.

\section{Conclusion}

This study has evaluated and demonstrated C. Oliffi as a potential biological control agent against $S$. squamosum. The study also established that the chironomid flies could successfully complete their development on a fish food diet only.

\section{Competing interests}

The authors declare that they have no competing interests.

\section{Authors' contributions}

All the authors have contributed substantially to this study. DAB and MDW contributed intellectually to the conceptualization, design and initiation of both the study and manuscript preparation. EF carried out the laboratory and field studies. CAB and AG advised and contributed to the laboratory studies and manuscript preparation. JA contributed towards the identification of larvae.

\section{Acknowledgements}

We acknowledge the invaluable support of Mr Anthony Tetteh and Nana Afram during the collection of samples for this study. The manuscript benefited from the critical review by Prof. R. Cheke, University of Greenwich, England, UK. We are finally grateful to Prof. David Ofori-Adjei, former Director, Noguchi Memorial Institute for Medical Research for the permission to have this work reported. This study was supported with funds from a DAAD student fellowship to Mr E. Fokam

\section{References}

I. Falk S: Anaphylactic shock probably resulting from multiple Blackfly (Simulium) bites in the English Midlands. British Simuliid Group Bulletin 2002, I 8:4-6.

2. Hougard JM, Agoua H, Yaméogo L, Akpoboua KL, Sékétéli A, Dadzie KY: Blackfly control: what choices after onchocerciasis? World Health Forum 1998, I 9(3):28I-284.

3. Jamnback H: Recent developments in the control of black flies. Annu Rev Entomol 1973, I 8:281-304.

4. Borsboom G], Boatin BA, Nagelkerke NJ, Agoua H, Akpoboua KL, Alley EW, Bissan Y, Renz A, Yameogo L, Remme JH, Habbema JD: Impact of ivermectin on onchocerciasis transmission: assessing the empirical evidence that repeated ivermectin mass treatments may lead to elimination/eradication in WestAfrica. Filaria J 2003, 2(I):8.

5. Awadzi K, Boakye DA, Edwards G, Opoku NO, Attah SK, OseiAtweneboana MY, Lazdins-Helds JK, Ardrey AE, Addy ET, Quartey BT, Ahmed K, Boatin BA, Soumbey-Alley EW: An investigation of persistent microfilaridermias despite multiple treatments with ivermectin, in two onchocerciasis-endemic foci in Ghana. Ann Trop Med Parasitol 2004, 98(3):23 I-249.

6. Boakye DA, Awadzi K, Osei-Atweneboanah M, Attah S, Lazdins J: Efficiency of members of the Simulium damnosum Theobald in the uptake of microfilaria of Onchocerca volvulus at different microfilaria densities [abstract]. Am J Trop Med Hyg 2002, 67(2):s285.

7. Werner D, Pont AC: Dipteran predators of Simuliid blackflies: a worldwide review. Med Vet Entomol 2003, I 7(2): I I5-I32.

8. Harrison AD: Two small Orthocladiinae (Chironomidae, Diptera) from the Western Cape Province, South Africa. Ann Cape Prov Mus (Nat Hist) 1997, 19:375-386.

9. Fokam E: Preliminary studies on Cardiocladius oliffi (Diptera: Chironomidae) as a potential biological control agent of Simulium damnosum s.l (Diptera: Simuliidae) vector of onchocerciasis in West Africa. In MPhil thesis University of Ghana, Department of Zoology; 2000. 
10. Boakye DA, Back C, Brakefield P: Evidence of multiple mating and hybridization in Simulium damnosum s.l. (Diptera: Simuliidae) in nature. J Med Entomol 2000, 37(I):29-34.

II. Wiederholm T, (ed): Chironomidae of the Holarctic region. Keys and diagnoses. Part I. Larvae. Entomologica Scandinavica 1983:457.

12. Wiederholm T, (ed): Chironomidae of the Holarctic region Keys and diagnoses. Part 3. Adult males. Entomologica Scandinavica 1989:532.

13. Freeman P: A study of the Chironomidae (Diptera) of Africa South of the Sahara. Part II. Bull Br Mus Nat Hist 1956, 4:287-368.

14. Boakye DA: A pictorial guide to the chromosomal identification of the Simulium damnosum Theobald complex in West Africa with particular reference to the Onchocerciasis Control Programme area. Trop Med Parasitol 1993, 44:223-244.

15. Flook PK, Wilson MD, Post RD: The use of repetitive DNA probes in the analysis of natural populations of insects and parasites. In Genes in Ecology Edited by: Berry RJ, Crawford T], Hewitt GM. Oxford; Blackwell Scientific Publications; 2004:484-486.

16. Wilson MD: Morphological and molecular methods for the identification of adult female Simulium damnosum species complex (Diptera: Simuliidae) vectors of onchocerciasis. In $\mathrm{PhD}$ thesis University of Salford, Department of Biological Sciences; 1994.

17. Service MW, Elouard JM: Serological identification of the predators of the complex of Simulium damnosum Theobald (Diptera: Simuliidae) in the Ivory Coast. Bull Entomol Res 1980, 70:657-663.

18. Service MW, Lyle PTW: Detection of the predators of Simulium damnosum by the precipitin test. Ann Trop Med Parasitol 1975, 69(I): $105-108$.

19. Burton GJ, McRae TM: Observations on trichopteran predators of aquatic stages of Simulium damnosum and other Simulium species in Ghana. J Med Entomol 1972, 9(4):289-294.

20. Wu YF: A contribution to the biology of Simulium (Diptera). Pap Michigan Acad Sci 1931, 1 3:543-599.

21. Grenier P: Observations sur quelques stations de simulies. Parasites et predateurs des larves et nymphes. Bull Soc Pathol 1943, 36:105-110.

22. Grenier P: Remarques sur la biologie de quelques enemies des simulies. Bull Soc Entomol France 1953, 49:130-133.

23. Kureck A: Tagesrhytmen lapplandischer Simuliiden (Diptera). Oecologia 1969, 2:385-4I0.

24. Crosskey RW: The natural history of blackflies. New York: John Wiley and Sons; 1970.
Publish with Bio Med Central and every scientist can read your work free of charge

"BioMed Central will be the most significant development for disseminating the results of biomedical research in our lifetime. "

Sir Paul Nurse, Cancer Research UK

Your research papers will be:

- available free of charge to the entire biomedical community

- peer reviewed and published immediately upon acceptance

- cited in PubMed and archived on PubMed Central

- yours - you keep the copyright
BioMedcentral 